Stine Willum Adrian er ph.d. og cand.scient.soc. Hun er adjunkt i Teknoantropologi, Aalborg Universitet i København, og har skrevet ph.d.-afhandlingen Nye skabelsesberetninger om æg, sæd og embryoner: Et etnografisk studie af skabelser på sædbanker og fertilitetsklinikker. Adrian er pt. i gang med et forskningsprojekt om globalisering af dansk sæd og etik.

\title{
NATURLIGVIS? \\ Når lys, hunde og kønsceller sætter naturen til forhandling på fertilitetsklinikken
}

Hvad laver forestillinger om det naturlige på en fertilitetsklinik, og hvilke implikationer har anvendelsen af det naturlige, når praksisser etableres til at skabe børn via teknologi? Det er spørgsmål denne artikel rejser på baggrund af et etnografisk studie på fertilitetsklinikker i Danmark og Sverige, hvor forestillinger om det naturlige var centralt $i$ både laboratoriepraksisser og i de etiske grænser, der var sat via lovgivere. Artiklen undersøger fire forskellige situationer, der illustrerer, hvordan naturlighedens paradoks materialiserer sig på forskellige måder på fertilitetsklinikkerne, ofte med konsekvenser for humane og ikke-humane aktører. Artiklen peger derfor på behovet for at skabe en post-naturlig etik, der tager udgangspunkt i det grundlæggende spørgsmål, Cui bono?

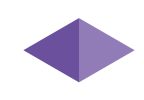

$\mathrm{H}$ vorfor arbejdes der i mørke i ét fertilitetslaboratorium, mens der arbejdes med lyset tændt $\mathrm{i}$ et andet? Hvorfor kan man ikke få lov til at vælge en sæddonor uden hundeallergi? Hvorfor visualiseres mødet mellem ét æg og én sædcelle overalt på fertilitetsklinikker, når der skal mange tusinde sædceller til en befrugtning? Og hvorfor er det ikke muligt at donere embryoner, når man kan donere æg og sæd?

Disse fire spørgsmål, som er omdrejningspunktet for den kommende analyse, var blot nogle af en lang række spørgsmål, jeg stillede, da jeg begyndte at udføre 
etnografisk feltarbejde på fertilitetsklinikker og sædbanker i Danmark og Sverige. ${ }^{1}$ Umiddelbart synes spørgsmålene ikke at have meget til fælles. Da jeg gik i gang med analysen af mit empiriske materiale, gik det dog op for mig, at langt størstedelen af de mest fascinerende spørgsmål rejste sig, fordi praksisser på fertilitetsklinikken former sig i forbindelse med, hvad jeg beskriver som naturlighedens paradoks. Med det mener jeg, at forestillinger om det naturlige anvendes til at skabe praksisser og/eller sætte etiske grænser for teknologiens anvendelse på trods af, at det naturlige ikke kan defineres, og at forestillingerne om det naturlige kommer til udtryk i et laboratorium, hvor børn bliver skabt ved hjælp af teknologi. Jeg blev derfor hurtigt fascineret af, hvordan naturlighedsforestillingerne kommer i spil, forandrer sig, og hvilken betydning de har for teknologiens brugere. ${ }^{2}$ Dvs. at jeg blev nysgerrig på, hvordan naturlighedens paradoks konstant kommer til udtryk og kan få omfattende konsekvenser for involverede aktører - humane som ikke-humane.

Interessen for samspillet mellem natur og kultur har igennem mange år været et centralt tema i kulturstudier, der forholder sig til teknologi. Donna Haraway har været med til at nuancere og muliggøre analyser af samspillet mellem krop og teknologi via sin figuration cyborgen, der åbner op for at tænke teknologi, dyr og menneske sammen og byder på raffinerede teknologianalyser, der hverken placerer sig som teknofobe eller teknofile, men som i stedet analyserer, hvordan teknologier indgår i et komplekst spil af normative forestillinger og magtforhold. På samme måde har hun introduceret figurationer som coyoten, der husker os på at inkludere de materielle overraskelser, som kroppe, celler, landskaber mv. byder på analytisk, og som denne artikel er dybt inspireret af (Haraway 1991).

I etnografiske studier om assisteret befrugtning har natur-kultur tematikken da også været et yndet genstandsfelt (Burfoot 1990; Cussins 1998; Franklin 1997; Franklin og Ragoné 1998; Strathern; Thompson 2005). Det, jeg i denne artikel konceptualiserer som naturlighedens paradoks, er således tidligere blevet udforsket og udfordret analytisk. I en række af disse studier er naturen som model blevet kritiseret, fordi den kan anvendes som legitimeringsstrategi for normer, der marginaliserer eller stigmatiserer fx lesbiske (Bryld 2001, Lykke \& Bryld 2006). Lykke \& Bryld har af samme grund argumenteret for udviklingen af en post-naturlig etik, der gør op med anvendelsen af det naturlige som model for etisk grænsesætning (Lykke \& Bryld 2006). De har blandt andet gjort mig etnografisk nysgerrig på at undersøge og udfolde, hvilke implikationer det at anvende det naturlige

1 Det feltarbejde artiklen baserer sig på fandt sted i 2002-2003. I 2012 påbegyndte jeg feltarbejde på danske fertilitetsklinikker og sædbanker igen.

2 Flere studier har analyseret, hvordan lesbiske og enlige er blevet stigmatiseret i de parlamentariske debatter pga. bestemte forestillinger om naturen. Liljestrand 1995; Bryld 2001; Adrian 2010. 
som etisk grænsesætter kan have for de aktører, der til dagligt indgår i fertilitetsbehandling på fertilitetsklinikker.

Den række af kulturstudier, der har analyseret anvendelsen af assisteret befrugtning, har dog hovedsageligt undersøgt forestillinger om natur i lyset af kulturelle normer og diskurser. Det, der til stadighed overrasker mig i mine etnografiske studier af assisteret befrugtning, er, hvordan teknologi, kroppe og celler konstant agerer overraskende og er direkte årsag til, at normer, også knyttet til forestillinger om natur, bliver sat til forhandling. Denne artikel bygger således videre på de allerede eksisterende, spændende og skarpe studier om, hvordan natur- og kulturforståelser etableres og forhandles normativt i forbindelse med anvendelsen af assisteret befrugtning. I denne artikel vil jeg dog bidrage med en analyse, der fokuserer på, hvordan også det materielles agens får betydning for forhandlingerne af forestillinger om det naturlige. Med forhandlinger mener jeg, hvordan både humane og ikke-humane aktører som teknologi, celler og kroppes forskellige former for agens får betydning for de forandringer og konkrete materialiseringer, der finder sted i forbindelse med arbejdet på at skabe børn. Forhandlinger skal i denne sammenhæng ikke forstås som, at aktører nødvendigvis bærer intentioner med sig i situationen, der er under forandring.

For at kunne inkludere materiel agens analytisk, for at undersøge hvordan naturlighedens paradoks kommer til udtryk, kræver det et teoretisk blik, der inkluderer muligheden for, at materialitet agerer og har forandringspotentiale; det tilbyder Karen Barads teori agential realisme. Teorien skaber mulighed for at forstå, hvordan forskellige former for aktører, materialiteter og normer kan påvirke og skabe forandringer, der materialiserer sig, herunder også forståelser af, hvad der opfattes som det naturlige. Det er en teori, der forholder sig til, hvordan diskurser og materialitet er med til at skabe verden i samspil (Barad 2007). Jeg vil med andre ord undersøge, hvordan naturlighedens paradoks kommer til udtryk på fertilitetsklinikken via forskningsspørgsmålet:

Hvordan finder forandringer af forestillinger om det naturlige sted på fertilitetsklinikkerne i mødet mellem diskurser, celler, reproduktive teknologier og teknologiske brugere, og hvilke implikationer får anvendelsen af naturen som model for praksisser og som etisk grænsedrager?

Det vil jeg gøre ved først at forklare, hvordan jeg teoretisk og metodisk har skabt mulighed for at undersøge, hvordan naturlighedens paradoks kommer til udtryk på fertilitetsklinikker ved hjælp af agential realisme. For at få en indsigt i, hvordan forestillinger om det naturlige forhandles og hvordan det kommer til udtryk, undersøger jeg, hvad der sker i de situationer, der ligger til grund for de fire spørgsmål, jeg indledningsvist rejste i artiklen. Spørgsmålene er valgt ud fra, at de illustrerer, hvordan naturlighedens paradoks kommer til udtryk og har impli- 
kationer i forskellige situationer. ${ }^{3}$ I spørgsmålene har materiel og diskursiv agens forskellige udtryk, og det har forskellige implikationer for de forskellige aktører, der er delagtige i naturlighedsforestillingerne på fertilitetsklinikkerne. Det første spørgsmål: Hvorfor arbejdes der i mørke i ét fertilitetslaboratorium, mens der arbejdes med lyset tændt i et andet? - giver indblik i, hvorfor det kan give mening at anvende naturen til at skabe praksisser, og hvordan materialitetens agens spiller ind i forhandlingen af praksisserne i et laboratorium. Det andet spørgsmål: Hvorfor kan man ikke få lov til at vælge en sæddonor uden hundeallergi? - skaber indsigt i, hvordan det materielle, i form af en hund, åbner op for nye opfattelser af det naturlige i forhold til diskurser om slægtskab og donorvalg. Det tredje spørgsmål lyder: Hvorfor visualiseres mødet mellem ét æg og én sædcelle overalt på fertilitetsklinikker, når der skal mange tusinde sædceller til en befrugtning? I den del af analysen viser jeg, hvordan der kan opstå stigmatiseringer, der fører til diskrimination af enlige kvinder og lesbiske par via anvendelsen af forestillinger om naturen. Til sidst undersøger jeg spørgsmålet: Hvorfor er det ikke muligt at donere embryoner, når man kan donere æg og sæd? Svarene illustrerer, hvordan det materielles agens i form af embryoner fører til, at fertilitetspersonale udfordrer eksisterende slægtskabsforståelser. Afslutningsvis diskuterer jeg, hvad inklusionen af materialitetens agens kan bidrage til i en kulturanalyse, og hvilke konsekvenser naturlighedsparadokset kan få i praksis for teknologiens brugere.

\section{Agential realisme - et teoretisk afsæt til at undersøge naturlighedens paradoks}

For at det bliver muligt at undersøge, hvordan naturlighedens paradoks kommer til udtryk på fertilitetsklinikken, trækker jeg teoretisk på agential realisme, en teori udviklet af fysikeren Karen Barad. ${ }^{4}$ Udgangspunktet for teorien er kort fortalt at begrebsliggøre, hvordan viden bliver til og verden materialiserer sig. Det er derfor også en teori, der muliggør undersøgelser af fænomener, som både består af diskurser og materiel agens. Da jeg undersøger naturlighedens paradoks ved at se på, hvordan naturlighed forhandles og hvordan disse forhandlinger materialiserer sig både gennem materiel og diskursiv agens, mener jeg, at agential realisme er et teorivalg, der kan bidrage til det konceptuelle analytiske arbejde i denne ar-

3 Jeg har tidligere illustreret en lang række andre eksempler på, hvordan forestillinger om det naturlige kommer til udtryk på fertilitetsklinikker i Danmark og Sverige, Adrian 2006.

4 Jeg kunne have anvendt andre nymaterielle teorier og var i udgangspunktet inspireret af ANT, som jeg undervejs i mit arbejde valgte ikke at anvende, da det er svært at arbejde med subjektskabelse, der også er en stor del af hvad der finder sted på fertiltetsklinikken. At valget faldt på agential realisme skyldes dog også, at mit videnskabsteoretiske udgangspunkt er funderet i Haraways begreb om situeret viden, som er et grundlæggende udgangspunkt for agential realisme. For videre uddybning se Adrian 2006. 
tikel. Samtidig kræver det en vis oversættelse, når teorien skal anvendes etnografisk. Det skyldes ikke mindst, at de begreber og den teoretiske begrebsramme, som agential realisme tilbyder, trækker på teoretiske forståelser hentet fra både naturvidensskab, humaniora og samfundsvidenskab. Det er en teoretisk tilgang, der videreudvikler Niels Bohrs fysik-filosofi og Donna Haraways indsigter i forhold til teknologi og videnskabsteori og derudover bygger videre på Michel Foucault og Judith Butler. ${ }^{5}$ Agential realisme bryder med Decartes' adskillelse af subjekt og objekt, natur og kultur, materialitet og diskurs, epistemologi og ontologi. Agential realisme er en teori, der er skabt med et sprog, der overskrider disse dualismer. Begreberne bidrager til, at det bliver muligt at konceptualisere, hvordan viden og verden skabes via både materiel og diskursiv agens, der i Barads optik er uadskillelige, det er materielt-diskursivt. Selvom en del af begreberne sprogligt kan virke kringlede, gør de et væsentligt og anderledes analytisk arbejde, som ikke er muligt uden dem.

Barads opfattelse af, at verden og viden er materielt-diskursiv, bygger på den centrale præmis, at verden og viden skabes gennem performativ handlen. Barad både trækker på og videreudvikler Butlers forståelse af performativitet, som Butler anvender til at forklare, hvordan diskurser materialiserer sig. Butler eksemplificerer bl.a. hvordan de gentagelser af køn, som fx foretages af drags i form af citerende praksis, ender i en form for parodi med forandringspotentiale for subjektet (Butler 1990, s. 134-141). Den performative position indtager Barad som et alternativ til realismen, der hersker indenfor naturvidenskab, og den sproglige vending, der længe har defineret store dele af samfundsvidenskab og humaniora. Barad argumenterer således for at videreudvikle Butlers analytiske greb til også at kunne forstå, hvordan materialitet agerer via performativitet. Det skyldes, at hun mener, at både realismen og den sproglige vending fører til repræsentationalisme. Hvor realisterne mener, at verden kun kan forstås direkte gennem ting via neutrale måleapparater, så mener Barad, at sproget får tillagt så stor betydning i den sproglige vending, at viden opfattes som noget, der kun kan skabes via sproget - herunder også forskerens. Samtidig bliver materialiteters agens usynlig (Barad 2003, s.801-811). Med et fokus på performativitet får både sprog og materialitet mulighed for at agere og have effekt i forhold til, hvordan viden og verden materialiserer sig i et samspil, dvs. materielt-diskursivt. ${ }^{6}$ Med andre ord mener hun ikke, at sprog og ting kan analyseres separat, vi må analysere og forstå vores genstandsfelter, i denne artikel naturlighedens paradoks, som ét fænomen .

5 Barad bygger på Michel Foucault og Judith Butler. Samtidig kritiserer hun dem for hovedsageligt at fokusere på hvordan diskurser materialiserer sig, og ikke inkludere hvordan materialitet påvirker diskurser. Hun indskriver dem herved også i "the linguistic turn", som hun kritiserer. Barad, 2003,s. 808-811.

6 Den analytiske anvendelse af performativitet har en længere genealogi, men Barads tilgang tilføjer et posthumant perspektiv. Dvs. at performativitet ikke kun tillægger mennesker, men også andre aktører agens. 
Begrebet fænomen henter Barad fra Niels Bohrs fysik-filosofi. Begrebet tager udgangspunkt i opstillingen af eksperimenter i kvantefysik. Via dobbeltspalte gedankeneksperimentet argumenterede han bl.a., at apparaturet, dvs. opstillingen af eksperimenter, herunder også forskeren, påvirker og er del af den viden, der materialiserer sig (Barad 2007). I dobbeltspalteeksperimentet får det betydning for, om lys materialiserer sig som partikler eller bølger. Apparatur er her ikke blot materialitet, apparaturet er i lige så høj grad konceptuelle opfattelser, der indgår i dets etablering. ${ }^{7}$ Forståelsen af fænomenet og apparaturet overlapper, for via etableringen af apparaturet opstår det fænomen, der skaber viden og materialiserer sig. Fænomenet er med andre ord et samlebegreb for alle de elementer, der etablerer sig og indgår i en materialiseringsproces. Derfor kan forestillinger om fx slægtskab og seksualitet mv. betragtes som del af apparaturet, hvis det har effekt for den viden, der skabes, og de materialiseringer, der finder sted. I Barads optik er der derfor ikke blot tale om, at det er en interaktion af forskellige elementer, der finder sted - elementerne bliver et hele, og der opstår hvad hun kalder intraaktion, der konstant forandrer, rekonstituerer og materialiserer sig iterativt. Det er præcis denne iterative performativitet, der etablerer forandringer på linje med de parodier, Butler viser kan materialisere sig gennem diskursive citerende gentagelser. Denne proces har jeg valgt at kalde performative forhandlinger. Begrebet performative forhandlinger af det naturlige skal forstås som den proces, der finder sted i de meget komplekse situationer, hvor forandringer finder sted gennem iterativ materielt-diskursiv intra-aktion. I nogle tilfælde indgår menneskers intentioner, men ikke altid og de fleste ikke-humane aktører agerer uden intention. Da forskeren ikke kan opfattes som udenforstående ift. den viden, der skabes, så følger der et stort forskeransvar og forskningsetik med, som denne artikel er optaget af. Det gør sig gældende både i forhold til egen forskerpraksis, men også i forhold til de uligheder der kommer til udtryk i forskningsfeltet, hvilket former min interesse for at undersøge, hvilke implikationer naturlighedens paradoks har for de implicerede aktører på fertilitetsklinikker. ${ }^{8}$

De fire spørgsmål, jeg tager udgangspunkt i i denne artikel, er del af et større etnografisk feltarbejde, der var designet til at skabe indsigter i de materielt-diskursive skabelser, der opstår på fertilitetsklinikker og sædbanker i mødet mellem humane og ikke-humane aktører. Mit forskningsdesign var således konceptuelt udviklet til at undersøge samspillet mellem materialitet og diskursers agens. For at sikre mig muligheden for at undersøge materielt-diskursive fænomener valgte jeg at følge kønscellerne æg, sæd og embryoner rundt på sædbanker og fertilitetsklinikker. Mit felt blev med andre ord etableret ved at følge æg, sæd og embryoner

7 Apparatur er et begreb, der både er inspireret af Bohr, Haraway og Foucault. Der er en direkte kritik af den gængse etablerede naturvidenskabs syn på objektivitet (Barad 2007).

8 Barad arbejder derfor aktivt med at skabe forskningsetik, hvor forskeren påtager sig ansvar for de materialiseringer, hun er del af (Barad 2007: 353-396). 
som hvad Haraway har beskrevet som imploderede knuder. En imploderet knude er ifølge Haraway en knude, der kan følges som et garnnøgle, der bliver viklet op og kan åbne op for nye verdener, der består af både materielle og diskursive relationer (Lykke 2000:58). Det medførte et multi-sitet feltarbejde (Marcus 1998). Et feltarbejde hvor jeg fulgte henholdsvis æg, sædcelle og embryon fra de ikonografiske billeder, der er at finde fra informationsmateriale fra sædbanken, ind og rundt på fertilitetsklinikken, ligesom jeg undersøgte, hvordan narrativer fra medier, lovgivning og internet var del af de skabelser, der fandt sted i forbindelse med anvendelsen af assistereret befrugtning. Jeg udførte feltarbejde på en dansk fertilitetsklinik, en svensk fertilitetsklinik, en dansk sædbank, en svensk kombineret sædbank og inseminationsklinik og en dansk inseminationsklinik. Alle steder udførte jeg observationer, og i alt foretog jeg 42 semistrukturerede interview med personale og patienter. Derudover inddrog jeg informationsmateriale, lovgivningsmateriale, reklamemateriale og websider i mine analyser. Alt materiale anvendt i denne artikel er anonymiseret. For en uddybning af de metodologiske overvejelser, der fulgte i ønsket om at undersøge materielt-diskursive skabelsesprocesser, se (Adrian 2006, s. 49-87; Højgaard og Søndergaard 2010, s. 327-330) .

Med begreberne fra agential realisme og en metodologisk beskrivelse, der har formet mit feltarbejde, har jeg nu analytiske greb til at undersøge de processer, der finder sted i forbindelse med de fire spørgsmål, hvor naturlighedens paradoks folder sig ud på forskellige måder.

\section{Naturen til forhandling i laboratoriet}

Hvorfor arbejdes der i mørke i ét fertilitetslaboratorium, mens der arbejdes med lyset tændt $i$ et andet?

Dette spørgsmål opstod, da jeg efter at have udført feltarbejde på fertilitetsklinikken i Danmark begyndte mit feltarbejde på en fertilitetsklinik i Sverige. Indtil da havde jeg taget laboratoriepraksisserne på klinikken i Danmark for givet som den måde, der arbejdes i et fertilitetslaboratorium. Jeg havde med andre ord ikke fået blik for, hvordan lyssætning og laboratoriepraksisser tog del i naturlighedens paradoks, og hvordan forestillinger om det naturlige kunne blive forhandlet $\mathrm{i}$ forbindelse med laboratoriepraksisser. På klinikken lå laboratoriet med fin udsigt og store vinduer, og der var masser af lys, når sæd blev tilføjet til æggene i petriskålene.

Da jeg begyndte mit feltarbejde på den svenske fertilitetsklinik, blev jeg derfor noget overrasket over laboratoriets placering på klinikken. Det lå i midten af bygningen uden lys fra vinduer, og lyset i loftet var slukket, så der var mørke i rummet. 
Under rundvisninger med nye patienter blev det klart, hvad der på den svenske klinik blev opfattet som god laboratoriepraksis. Nedenfor er et udsnit af mine feltnoter fra rundvisningen.

"Sygeplejersken Sara åbner døren ind til et lille rum, der fungerer som mellemgang mellem resten af klinikken og operationsrummet og laboratoriet. Både operationsrum og laboratoriet er, hvad de beskriver som sterile områder. Man skal derfor have hvid kittel over tøjet, papirhat på hovedet og andre sko eller skobeskyttere på, når man går ind. Det er et udstyr, som var ganske uvant for mig, efter at have befundet mig på den danske klinik.

Laboratoriet og operationslokalet er samtidig områder, hvor man ikke kan se ind. Wera, en af bioanalytikerne, kommer derfor i stedet ud og fortæller om, hvad de laver på laboratoriet. Det er her, de udfører befrugtningen. Hun forklarer, de forsøger at skabe så "naturligt” et klima for æg og sæd som muligt, så derfor er der mørkt som i livmoderen. Agg, sæd og embryoner kan ikke tåle lys. I tiden uden for kroppen opbevares æg og sæd i inkubatorer (varmeskabe), der har et klima, der er så tæt på kroppen som muligt. Inkubatorerne sørger for, at der er den rette temperatur og $\mathrm{CO}^{2}$ indhold."

Jeg fulgte rundvisningen af patienter en af de første dage, jeg lavede feltarbejde på den svenske klinik. Med tanke på mit tidligere feltarbejde på den danske klinik blev det tydeligt for mig, at fertilitetsklinikkerne bliver iscenesat, og arbejdet performet på forskellige måder (Adrian 2006, 89-128). Alle de praksisser, der finder sted, kan opfattes som performative. På laboratoriet blev den performative praksis ikke mindst tydelig ift. den måde, lys blev anvendt forskelligt på de to klinikker. Under rundvisningen på den svenske klinik blev patienterne introduceret til de praksisser, der fandt sted, og de lærte, hvordan det forventes, de selv skal performe og handle under behandlingen. Det er under rundvisningen, at forklaringen på laboratoriets scenografi italesættes. Laboratoriet holdes sterilt og mørkt. Det er placeret med to døres adskillelse fra den gang, hvor vi under rundvisningen befinder os. I stedet for at se laboratoriet fyldes denne del ud med en beretning om, hvordan æg, sæd og embryoner bliver behandlet så tæt på det naturlige som muligt; det gøres ikke mindst klart ved, at bioanalytikeren nævner, at livmoderen fungerer som model for deres arbejde og for inkubatorerne, hvor æg, sæd og embryoner opbevares, når det befinder sig udenfor livmoderen. Herved forsøger man på klinikken at skabe så optimale betingelser for æg, sæd og embryoner som muligt. Inkubatorerne fuldender dette ved ikke blot at efterligne livmoderen ift. lys men også i forhold til luftfugtighed og temperatur.

Da jeg efterfølgende stillede spørgsmålet, om der var forskel på danske og svenske æg og sæd ift. lysfølsomhed, grinede både det danske og svenske personale. På den lyse danske klinik viste det sig, at de tidligere også havde haft 
lyset slukket og havde arbejdet i mørke. På et tidspunkt havde en kollega tændt lyset, og det havde ikke påvirket succesraten. Derefter havde de valgt at arbejde i lys.

På den mørke svenske klinik vidste de godt, at andre arbejdede i lys, men mørket var blevet en del af den beretning, de havde bygget deres praksis op efter, og det ønskede de ikke at ændre på. Bioanalytikerne var helt enkelt nervøse for, at deres gode succesrater kunne falde, hvis de tændte lyset. Lyset var blevet en del af deres performative praksis. Argumentationen fra bioanalytikerne på den svenske klinik kan synes morsom - men analyseres den i Barads optik med udgangspunkt i fænomenet, giver det god mening. Lyset og fortællingen om livmoderen indgår helt enkelt i en materielt-diskursiv materialiseringsproces, der finder sted i form af det fænomen, der etablerer sig i deres arbejde med at gøre kvinder gravide. I materialiseringsprocessen er det ikke muligt at adskille forestillingen om livmoderen, den performative praksis hvor lyssætning indgår og arbejdet med æg, sæd og embryoner. På trods af, at bioanalytikerne ved, at lys ikke nødvendigvis ændrer på succesrater, så er lyssætningen en del af hele deres praksis.

Den performative forhandling, der har fundet sted i forhold til forestillinger om naturen på den danske klinik, skal samtidig læses som en forhandling og ikke en forkastelse af naturen som model for deres praksis. På den danske klinik var inkubatoren, hvor æg, sæd og embryoner blev opbevaret, stadig bygget op med udgangspunkt i livmoderen, der inkluderede særlige forhold ift. temperatur og fugtighed, hvilket de også understregede, da jeg konfronterede dem med de lysfølsomme æg, sædceller og embryoner i Sverige.

Umiddelbart er det her blot en morsom anekdote fra mit feltarbejde - men den giver indsigt $i$, hvordan forestillinger om det naturlige som et materielt-diskursivt fænomen bliver rekonfigureret på forskellige måder. Eksemplet med lyset kan dog også være med til at give en forklaring på, hvorfor forestillingen om det naturlige ofte efterlignes. Det giver god mening at følge kroppens processer, når man ønsker at få æg, sæd og embryoner til at agere på samme måde, som de gør inde i kroppen - men eftersom befrugtningerne ikke finder sted i kroppen, opstår naturlighedens paradoks. Og skabelsen af børn i laboratoriet åbner i stedet op for spørgsmål om, hvad der er naturligt, og hvilke dele af kropslige processer, der er væsentlige at performe for at skabe befrugtede æg og graviditeter.

\section{Når forestillinger om naturligt slægtskab udfordres af menneskets bedste ven}

Det andet spørgsmål lyder: Hvorfor kan man ikke få lov til at vælge en sæddonor uden hundeallergi? Det opstod, da jeg interviewede Malin og Lars i Sverige. De havde fået en søn ved at bruge sæddonation. Under interviewet fortalte de mig 
om deres overvejelser om valg af donor, og deres oplevelse af hvordan bioanalytikeren, der valgte donor til dem, fik tydeliggjort, hvordan naturlighedens paradoks er i spil ved sæddonation i Sverige.

Hemmeligholdelse af sæddonation blandt heteroseksuelle var selv i Sverige almindeligt (Gotllieb et al. 2000). Dette på trods af, at man i Sverige har en lovgivning, der gør anonym donation ulovlig med argumenter om, at barnet har ret til at kende sit biologiske ophav, ${ }^{9}$ og at man i rådgivning til forældrene lægger stor vægt på, at de bør fortælle barnet, hvordan det er blevet til.

Lars og Malin havde dog i tråd med den svenske politik og klinikkens anbefalinger valgt, at de ville fortælle deres barn om, at han var blevet til ved hjælp af sæddonation. Da den svenske politik på området er meget klar, var det kommet bag på Lars og Malin, at princippet for at udvælge donor var, at han skulle ligne den kommende far. En slægtskabsopfattelse, der efterligner forestillingen om en forplantning, hvor det forventes, at genetiske børn ligner deres biologiske ophav.

For Lars og Malin begyndte forhandlingen af slægtskab og familie, før deres søn blev født. Ser man skabelsen af deres søn som en materialisering gennem Barads begreb fænomenet, består denne skabelse ikke blot af lovgivning, klinik, sæd og Malin og Lars, men også af deres hund.

Hunden havde de fået, inden de gik i behandling. De ville meget gerne have, at den fortsatte med at være del af familien. Derfor spurgte de, om det kunne lade sig gøre at få en donor uden hundeallergi. På trods af, at det var et udvælgelseskriterium, der i deres familie gav rigtig god mening, var og er det ikke muligt i Sverige. Med introduktionen af lovgivningen om anvendelse af sæddonation kan man argumentere, at ærlighed mellem forældre og børn er blevet til et nyt naturligt gode, hvilket i stigende grad bliver understøttet ved muligheden for at teste genetisk slægtskab via faderskabstest. Eftersom Malin og Lars havde besluttet at følge anbefalingen om at fortælle deres barn, at det var blevet til ved hjælp af en donor, virkede det dog mærkværdigt, at man ved udvælgelsen af sæddonor gik mere op i, at barnet kom til at ligne manden, end at deres elskede hund fortsat kunne være et fuldgyldigt medlem af familien.

For familien bliver et selektionsprincip baseret på forestillingen om, at man som biologisk beslægtet ligner hinanden, bizart og modsætningsfyldt, da det både tydeliggør tabuet omkring anvendelsen af en donor - der fysisk forsøges skjult gennem donorvalg - samtidig med, at parret ikke havde mulighed for at optimere muligheden for at undgå hundeallergi hos deres kommende barn. For dem var det vigtigere, at hele familien kunne blive ved med at leve sammen - inklusiv hunden. Derfor ville de hellere have haft en donor uden dyreallergi end en, der lignede Lars. Som Haraway med udgangspunkt i sin "The Companion Species Manifesto" nok ville sige, så kommer "companion species" (ikke mindst hunde!)

9 Lag (1984:1140) Lag om insemination, ändring införd: t.o.m. SFS 2005:443. 


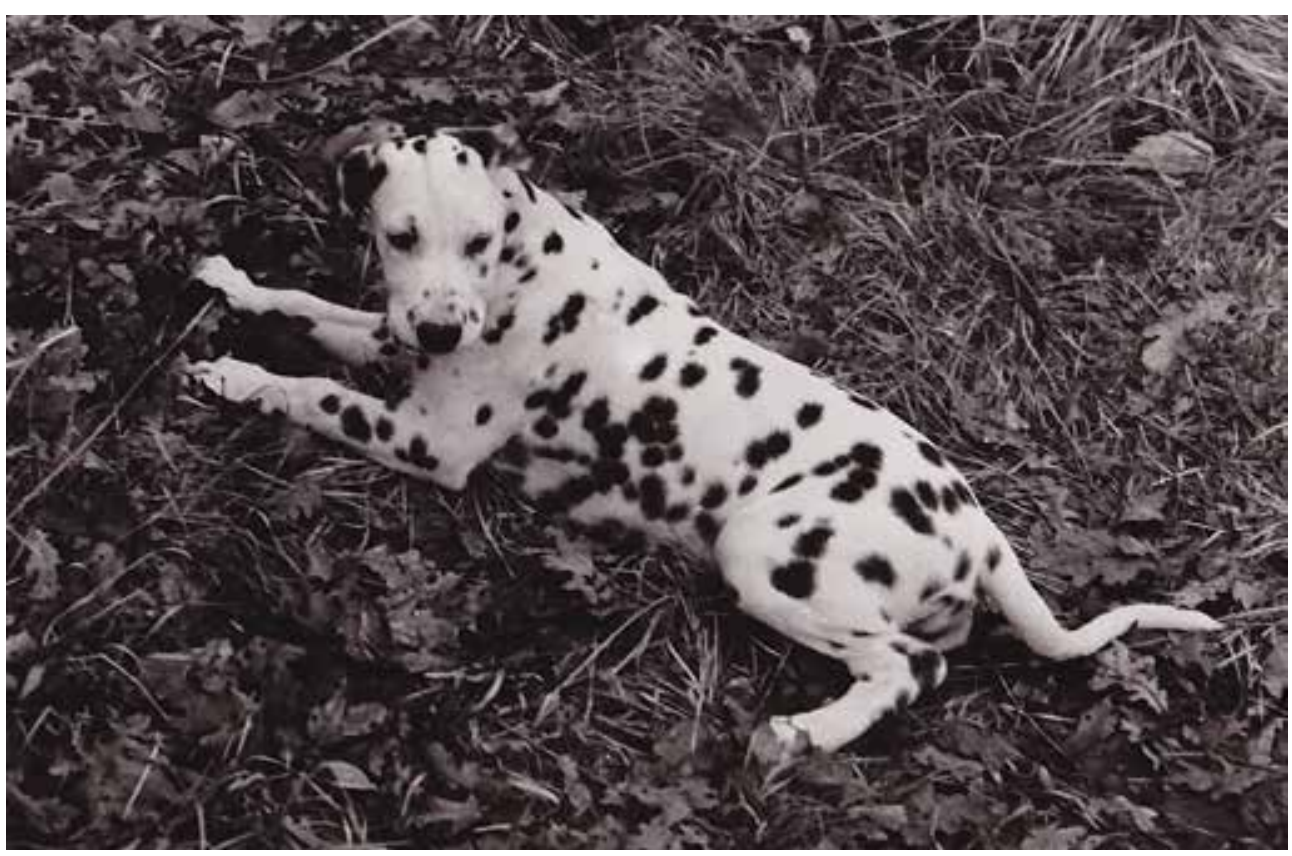

Foto: Stine W. Adrian

før genetisk slægtskab (Haraway 2003). ${ }^{10}$ Lars og Malin ønskede med andre ord at skabe et barn med en anden form for genetisk slægtskab. Her er der ikke tale om et slægtskab, der er baseret på at efterligne en forestilling om naturen i form af fysisk lighed med faderen. I stedet ønskede de at skabe et slægtskab, der inkluderede deres hund. Det er et slægtskab, man kan argumentere for, stadig bygger på en forestilling om "det naturlige", da de i stedet for, at barnet skal ligne, ønsker at efterligne Lars' evne til at tåle hunde og andre husdyr.

Eksemplet illustrerer, hvordan et fænomen, der er materielt-diskursivt for patienter, kan føre til forhandling af den eksisterende lovgivning og de eksisterende modsætningsfulgte slægtskabsdiskurser. For mig åbnede Malin og Lars' eksempel op for en undren over, hvordan naturlighedens paradoks kan komme i spil på en ny måde, da en familie bestående af et par og en hund forsøgte at skabe et barn, der kunne blive del af familien. I den konkrete situation var det ikke muligt for Lars og Malin i praksis at udfordre lovgivningen. Den søn de fik, var et resultat af et fænomen, der bl.a. bestod af en lovgivning, der fastlagde en praksis, der bygger på, at far og søn ligner hinanden, og at barnet har ret til at kende sit biologiske ophav. Naturlighedens paradoks får betydning for, hvilke selektionskriterier der er er gyldige, og hvilke der ikke er gyldige, når donoren skal vælges. Havde Malin og Lars haft samme ønske på daværende tidspunkt i Danmark, var de blevet

10 Haraways The Companion Species Manifesto: Dogs, People, and Significant Otherness, er hendes andet manifest (Haraway 2003). Manifestet handler om samspillet mellem "companion species" som f.eks. hunde og deres menneskelige ejere. Ligesom Haraways andre figurationer som $\mathrm{fx}$ cyborgen, anvender hun "hunden" til at vise nedbrydningen mellem natur/kultur. 


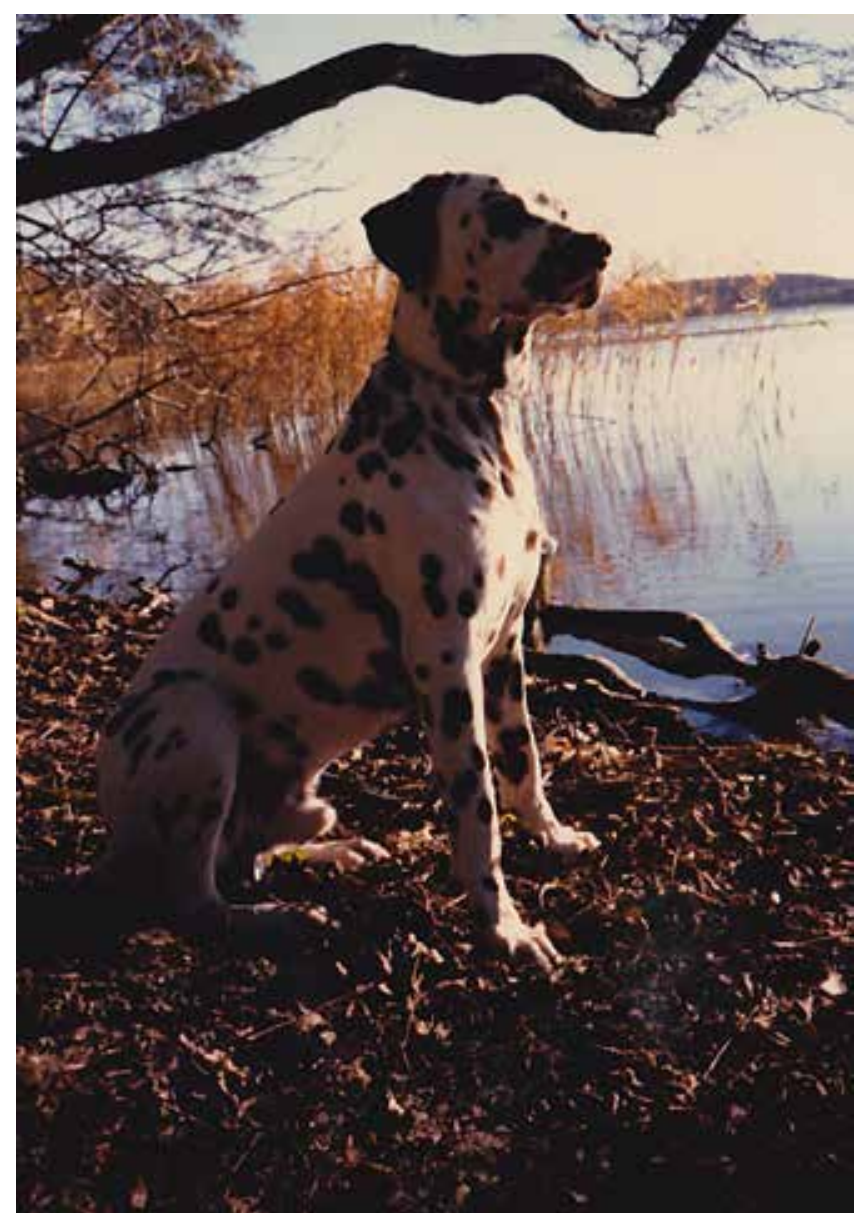

\section{Foto: Stine W. Adrian}

mødt med samme opfattelse som i Sverige, da lovgivningen og praksis var meget lig hinanden på dette felt (med den store undtagelse at kun anonym donation var tilladt, hvilket muligvis havde gjort, at de ikke i samme grad havde studset over udvælgelsesprincippet for sæddonor). Siden 2003, hvor interviewet med Malin og Lars fandt sted, er der dog sket en stor forandring i praksis og lovgivning i Danmark. I dag er det uanset kliniktype muligt i Danmark at vælge donor ud fra mange forskellige selektionskrav. En donor kan fx være enten anonym eller ikke anonym, og en lang række af donorerne har, hvad der beskrives som udvidede profiler, hvilket muliggør, at man kan vælge en donor uden hundeallergi. I fænomenet donorvalg bliver forestillingen om "det naturlige" i form af et genetisk slægtskab, hvor barnet ligner far, mor eller medmor, med andre ord i dag i Danmark materielt-diskursivt forhandlet dagligt. 


\section{Når forestillinger om naturen forhandles af donorbørn og deres forældre...}

Det tredje spørgsmål lyder: Hvorfor visualiseres skabelsen af et barn som mødet mellem ét æg og én sædcelle overalt på fertilitetsklinikker, når der for det meste skal mange tusinde sædceller til en befrugtning? Umiddelbart virker dette billede uskyldigt og sjovt, men den kendte historie har haft væsentlige implikationer for brugere af assisteret befrugtning og viser, at naturlighedens paradoks ikke er uskyldigt, men kan have stigmatiserende og ekskluderende effekt.

Mødet mellem én sædcelle og ét æg er en af de mest gennemgående visualiseringer, jeg har mødt på fertilitetsklinikker. Ofte er beretningen anvendt som logo, samtidig som billedet går igen i reklamemateriale for de hormoner, de farmaceutiske firmaer sælger til kvinder i hormonbehandling. Fx anvendte Serono, et af de største farmaceutiske firmaer, der udvikler hormoner til fertilitetsbehandling, op igennem 00'erne en fotomanipuleret billedserie af mødet mellem ægget og sædcellen, der efterfølgende udvikler sig til et embryon (befrugtet æg). Jeg var gennem mit feltarbejde dybt fascineret af, hvorfor man på en fertilitetsklinik anvendte denne visuelle skabelsesberetning så massivt, eftersom denne performativitet står i modsætning til, hvad der konkret sker i laboratoriet (Adrian 2006, 129-142). For i praksis skal der millioner af levende sædceller til for at sandsynliggøre en graviditet ved insemination og mange tusinde sædceller ved en almindelig IVFbehandling, hvor æggene er taget ud og befinder sig i en petriskål, inden sædceller tilføres, og en befrugtning finder sted. Til gengæld skal der kun én sædcelle og ét æg til en befrugtning, når bioanalytikeren udfører mikroinsemination, dvs. når hun ved hjælp af pipetter under mikroskop injicerer en sædcelle ind i ægget - en sædcelle, der tilmed har fået slået halen af inden. Derfor spurgte jeg ind til det under mine interview med klinikpersonalet heriblandt Sara, der er jordemoder på en svensk fertilitetsklinik, der anvendte billedet af mødet mellem ét æg og én sædcelle som logo:

"Stine: Hvem har egentlig fundet på jeres logo [møde mellem ægget og sædcellen]?

Sara: Ja, det er jo Bertil [en af lægerne], der har fundet på det, men det er jo ikke alle, der kan lide det.

Stine: Hvorfor kan de ikke det?

Sara: Det er ikke så mange, der ikke kan lide den, men jeg tror, der er mange, der synes at den... Han syntes, den var enormt fræk, da han fandt på den. Stine: Ha ha ha 


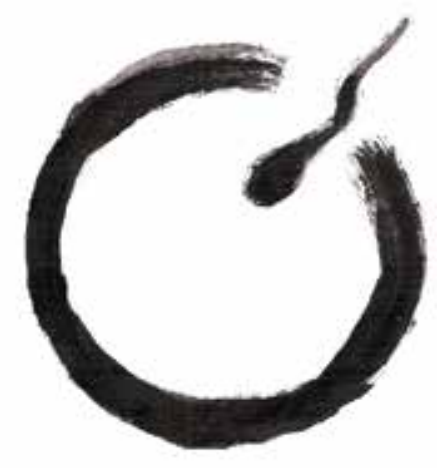

Illustration: Stine W. Adrian

Sara: Han synes den var enormt fræk, og jeg synes den var lige i overkanten, ${ }^{11}$ ohh han synes, den var enormt fræk. De fleste patienter, de siger ingen ting, men der findes jo nogen, som synes den er lige i overkanten, som ikke bryder sig om den. Desuden, på vores webside, der er den jo lidt sådan her (med en finger viser hun, at sædcellen svømmer med halen).

Stine: Ha ha ha.

Sara: Ja, han syntes, den var så fræk.

Stine: Det er jo lidt sjov, for normalt er der ikke bare..., det er jo kun ved ICSI, der er én sædcelle, ellers er der jo mange.

Sara: Ja, ellers er der mange, ja, det er et ICSI-logo, det er det, ha ha ha...

Stine: Ja, ha ha ha.

Sara: Ja, faktisk, det er det. Det har jeg ikke tænkt på.

Stine: Ja, det er ligesom Seronos billeder, I har hængende på køleskabet, der er også bare én.

Sara: Ja, det er sandt, det har jeg faktisk aldrig tænkt på, men det er jo rigtigt. Stine: Det ser jo ikke ud på den måde, så jeg har undret mig over, hvorfor gør man sådan?

Sara: Ja, det ved jeg ikke rigtigt.”

Via beskrivelsen af den frække sædcelle peger Sara i interviewet på, at der ligger en seksualiseret opfattelse af mødet mellem æg og sæd. Det er konnotationer, der kommer frem på trods af, at befrugtningen finder sted uden hverken romantik eller sex. Denne læsning illustrerer, at æg og sæd, når de ikonografisk vises sammen, er koblet til kønnede og seksualiserede metaforer. Det sker, selvom de bliver til kropsuafhængige aktører under fertilitetsbehandling efter at være blevet taget ud af kroppene. Saras læsning illustrerer således, at billedet af ægget og sædcellen kan læses som det heteroseksuelt romantiske møde, som Emily Martin tidligere har læst ud af medicinske lærebøger (Martin 1991). Her er ægget den passivt

11 Interviewet foregik på svensk. Sara udtrykker sig i et stærkt ironisk tonefald, og anvender det svenske ord "lagom", der betyder tilpas - hverken for lidt eller meget, men når lagom anvendes med tyk ironi får det en anden klang. Derfor har jeg oversat det til "i overkanten". 
ventende kvinde, der venter på, at den eneste ene kommer og tager hende - sædcellen bevæger halen - hvorefter der opstår sød musik, og et barn bliver til.....

Sara, der som jordemoder på en fertilitetsklinik varetager den tætte kontakt med patienter, oplever ind i mellem, at nogle af patienterne ikke bryder sig om logoet, bl.a. fordi det er seksualiseret. Man kan argumentere, at beretningen som fortælles via ægget og sædcellen er bygget op om en stereotyp kærlighedshistorie. Det er en stærk kulturel beretning, der også cirkulerer i børnebøger om, hvordan børn bliver til (Tjørnhøj-Thomsen 1999), og har gjort det længe før assisteret befrugtning blev udviklet. Derfor er historien både populærgenkendelig for fertilitetsklinikkens personale og de mænd og kvinder, der kommer på klinikkerne for at gennemgå fertilitetsbehandlinger. Med andre ord er det en heteroseksuel romantisk skabelsesberetning, der efterligner forestillingen om, hvordan seksuel reproduktion fører til børn med et lykkeligt kernefamilieliv til følge.

Når denne skabelsesberetning, der som tidligere nævnt er blevet anvendt i børnebøger og i medicinske tekstbøger, bliver hevet ind i forbindelse med anvendelsen af assisteret befrugtning på en fertilitetsklinik, så bliver det ikke blot en beretning, der lægger op til en heteronormativ performativitet, kærlighedsberetningen usynliggør samtidig anvendelsen af teknologi. Det er interessant, fordi behandling på en klinik kræver både ultralyd, avancerede mikroskoper, inkubatorer, medier (væsker som æg og sæd opbevares i), hormoner, pipetter mm., der udelades fra det ikonografiske billede. Samtidig usynliggøres de mange slægtskabsmuligheder og familieformer, som teknologien muliggør, når seksualitet og reproduktion adskilles. Fx familier bestående af lesbiske og enlige mødre.

Det er med andre ord en særlig forestilling om "det naturlige", der er at finde i denne beretning, der kommer til at stå overfor det teknologisk skabte, når beretningen bevæger sig ind i det kliniske rum. Det naturlige opløftes til at være bedre end anvendelse af teknologi. Dvs. at historien er med til at rekonstituere forestillingen om det naturlige og normale ved at fastholde og indskrive mødet mellem æg og sæd i en heteroseksuel kærlighed/seksualitet. Selvom mødet mellem æg og sæd ser ganske anderledes ud i laboratoriet, er det heteroseksuelle møde så normaliseret, at denne forskel er usynlig for Sara, der ikke har reflekteret over det før i interviewet, hvor hun grinende konkluderer, at de på klinikken har et ICSI-logo. At beretningen er så stærk, at Sara ikke tidligere har reflekteret over de forskelle, der er mellem den og praksisser i laboratoriet, er ikke overraskende set i lyset af betydningen, som seksuel reproduktion har haft i bl.a. lovgivningsarbejdet i både Danmark og Sverige. Da jeg udførte feltarbejdet, der ligger til grund for denne artikel, var det både ulovligt for læger i Danmark og Sverige at behandle lesbiske og enlige kvinder. I Danmark trådte først en lovgivningsændring i kraft i 2007, der sikrede lesbiske og enlige kvinders ret til behandling. I Sverige blev det lovligt for lesbiske at blive fertilitetsbehandlet i 2005, mens det endnu ikke er lovligt for enlige kvinder. Tidligere analyser af lovgivningsarbejdet har illustreret, at po- 
litikerne netop forsøgte at sætte etiske grænser for teknologien ved at efterligne forestillingen om seksuel reproduktion og herved "det naturlige" (Bryld 2001, Lykke og Bryld 2006, Liljestrand 1995).

Ligesom livmoderen bliver anvendt som performativ model i laboratoriet til at skabe et miljø for æg og sæd, der gennem performative forhandlinger forandres, så kan man argumentere for, at der fandt performative forhandlinger sted i forbindelse med anvendelsen af beretningen om ægget og sædcellen. Selvom lovgivningen på det pågældende tidspunkt, hvor mit feltarbejde blev udført, kun muliggjorde, at heteroseksuelle par kunne blive behandlet af læger, så forhandledes skabelsesberetningen og herunder mulige forældreskaber og slægtskaber i praksis. I Danmark skete der ikke mindst i 1999 og frem til lovgivningsændringen en forhandling af forestillingen om forældreskabsegnethed gennem etableringen af den jordemoderejede inseminationsklinik ejet af Nina Stork. Klinikken skabte mulighed for, at enlige og lesbiske kunne få barn via donorinsemination på trods af lovgivningen. Det var muligt, fordi jordemødre ikke var reguleret af lovgivningen. De mange konkrete børn, der blev til, og de mange kvinder, der gentagne gange gik i medierne og berettede om deres familier, var med til at skabe rum for at diskutere, om heteroseksualitet er udgangspunktet for forældreskab. I Sverige blev lovgivningen ændret for lesbiske i 2005, og i Danmark blev det lovligt for læger at behandle både enlige og lesbiske fra 1. Januar 2007. ${ }^{12}$ Siden er Danmark blevet et af de lande i Europa, der er er blevet kendt blandt enlige og lesbiske, der ønsker sig behandling med sæddonation. De kommer enten som tilrejsende eller køber sæd, de får tilsendt via UPS, til hjemmeinsemination. Det naturlige paradoks, der rejser sig i forbindelse med visualiseringen af mødet mellem ægget og sædcellen på fertilitetsklinikken, viser således, at forestillinger om det naturlige kan materialisere sig i form af en heteronorm praksis, der i værste fald kan være med til at materialisere sig som diskrimination. Samtidig viser den performative materiel-diskursive forhandling, der fandt sted, at de børn og forældre, der blev til gennem Storks subversive praksis, kan påvirke lovgivning og holdninger.

\section{Når celler udfordrer fertilitetspersonalets forestillinger om det naturlige slægtskab}

Hvorfor er det ikke muligt at donere embryoner, når man kan donere æg og sæd? Dette fjerde og sidste spørgsmål rejste sig under mit feltarbejde på den danske fertilitetsklinik. Spørgsmålet blev stillet af både lægen Lisbeth og bioanalytikeren

12 Jeg har tidligere vist at denne beretning også skaber problemer for heteroseksuelle mænd og kvinder pga. at stereotype kønsforståelser klistrer til "æg" og "sæd". Forståelser der er svære at leve op til som ufrivilligt barnløs. Adrian 2006, s. 129-292. 
Ulla, og rejser det sidste eksempel på, hvordan naturlighedens paradoks kan tage sig ud og få implikationer for humane og ikke-humane aktører.

Da jeg i 2002-2003 udførte feltarbejdet, var det blot tilladt at nedfryse befrugtede æg i 2 år i Danmark. Lovgivningen blev efterfølgende ændret, så det fra 2007 til i dag er lovligt at fryse og opbevare befrugtede æg i op til 5 år. ${ }^{13}$ Til gengæld var og er det ikke lovligt både at anvende sæd- og ægdonor i hverken Danmark eller Sverige. Lovgivningen skal med andre ord sikre genetisk slægtskab til mindst én af de kommende forældre. Man kan argumentere, at lovgivningen herved forsøger at fremhæve det genetiske slægtskab som naturligt og herved mere væsentligt end andre former for slægtskabsrelationer. Som etnograf var det derfor overraskende og interessant, at Ulla og Lisbeth udfordrede privilegeringen af det genetiske/ biologiske slægtskab, som de samtidig dagligt var med til at støtte via de performative skabende praksisser, de deltog i, når de hjalp par med at få biologisk egne børn på klinikken.

Det var blot ikke altid muligt at hjælpe par til at få børn med de æg og sæd, der var tilgængelige. Måske var der ikke æg og sæd, eller også agerede de på måder, der ikke skabte embryoner, der kunne udvikle sig til graviditeter: Æg, sæd og embryoner overrasker.

På laboratoriet var hele fokus på at få æggene til at blive befrugtet, udvikle sig og ende i graviditeter. Det var bioanalytikerne, der med stort engagement førte regnskab med graviditeterne. Graviditeterne blev indskrevet i logbøger i form af små hjerter ved siden af de niveauer af graviditetshormonet HCG, der var blevet målt hos kvinder via en blodprøve.

For bioanalytikeren Ulla blev det derfor problematisk, at hun samtidig skulle deltage i at destruere de befrugtede æg efter 2 år, når hun nu havde lagt et stort arbejde i at skabe dem, passe på dem og opbevare dem. For hende var det mulige liv. Hun forklarede mig:

"Jeg synes, at det er lidt synd, at loven siger, at vi ikke må beholde dem længere. Jeg sidder lige nu og rydder op i æg fra år 2001, og jeg skal smide 40 patienters æg ud, fordi de falder for aldersgrænsen, [...] og det synes jeg er mange." Stine: Hvordan har du det med at skulle smide embryoner ud?

Ulla: Det skal jeg jo. Jeg synes det er lidt synd for patienterne, og tænk hvis man kunne bortadoptere dem, ligesom man kan bortadoptere børn ik’. Det synes jeg, er en god idé."

13 Se Lov nr. 460 af 10. Juni 1997, Lov om kunstig befrugtning i forbindelse med lægelig behandling og Lov nr. 535 af 8. Juni 2006, Lov om ændring af lov om kunstig befrugtning i forbindelse med lægelig behandling, diagnostik og forskning m.v.

Under mit feltarbejde blev det lovligt i Sverige at anvende donorede æg, men ligesom med sæddonation var det kun muligt på offentlige klinikker. Derfor har jeg ikke materiale på ægdonation fra den svenske fertilitetsklinik. Lag (1991:115) Lag om atgärder i forskning- eller behandlingssyfte med ägg från människa, ändring införd: t.o.m. SFS 2005:39 
Med tanke på patienterne finder Ulla det trist, at de kun kan have deres embryoner i fryseren i to år. Problemet med dette tidsrum er, at har parret fået et eller to børn gennem behandlingen, men stadig har embryoner i fryseren, så er det tidligt at forsøge at opnå en ny graviditet indenfor tidsfristen.

I Ullas daglige engagement $\mathrm{i}$ at skabe liv bliver det mærkværdigt og modsætningsfyldt, at den performativitet, som lovgivningen er med til at forme, samtidig er med til at skabe en stor del spild og overskudsembryoner, der ender med at blive destrueret. Dette skyldes dog ikke blot den korte tidsmæssige grænse for opbevaring af embryonerne, men samtidig at embryoner i modsætning til f.eks. æg, er koblet til en mand og en kvinde. Ligesom i dag var der dengang stor mangel på ægdonorer i Danmark. Der var med andre ord mange par, der ikke kunne få de børn, de godt kunne tænke sig.

For Ulla var den iterative intra-aktion med æg, sæd og embryoner med til at skabe ideen om at "bortadoptere" de befrugtede æg væk til de par, der ikke kunne få donoræg - eller til de par der var så uheldige, at de begge var infertile. Lægen Lisbeth udtrykte samme holdning:

"Lisbeth: Taler vi om ægdonation og sæddonation, så kunne man spørge sig selv, når man smider æg ud, om man i stedet kunne adoptere et embryon. Det kan man jo ikke i dag, der kan man enten modtage sæd eller modtage et æg. Og enten sæden eller æg skal være fra den genetiske mor eller far.

Og hvis man nu har de børn, man gerne vil have, og æg i fryseren, så kunne det da godt være, at man kunne adoptere det lille barn der, eller det lille embryon der. Du undgår hormonbehandling og alt muligt andet, det er bare at tø det op og putte det op ik'...

Stine: Tror du, det ville være noget som..?

Lisbeth: Det vækker jo altid meget modstand ik', og det er jo noget frygtelig noget, for vi kan alle mene noget om det. For det er jo noget med livet og livets skabelse, det skaber altså et eller andet, der går i gang. 'Det lille barn har jo hverken sin far eller sin mor!' Jeg ved det ikke, jeg tror måske, ad åre måske...

Stine: Hvordan har du det med, at I smider embryoner ud?

Lisbeth: Det har jeg det selvfølgelig ikke godt med, det har jeg det ikke godt med. Det er jo potentielle liv, vi smider ud.

Stine: Du ser det som potentielle liv allerede fra...

Lisbeth: Ja, det er jo så lidt selvmodsigende, at jeg siger, at nu ligger det der på is, og det er jo ingenting vel, men det er jo noget med, at det kunne være blevet til noget ik'. Det er det der med, at man ved, hvor meget det betyder socialt og psykisk, det at få et barn. At det kunne være med til at blive til et barn. Og det vil jeg gerne hjælpe nogle mennesker til.” 
Hvor æg og sæd er noget der doneres, så får embryonet en væsentligt anderledes status. Det bliver ikke doneret, men adopteret, og fremstår på trods af dets stadie som celler nærmere muligheden for at være et potentielt barn. Lisbeths udgangspunkt for at foreslå, hvad hun kalder "bortadoption”, bygger på hendes syn på liv. Hun problematiserer med andre ord de praksisser, klinikken har for håndtering af mulige liv, der kunne blive til børn til glæde for barnløse. Hvis parret ikke er stærkt bundet af de eksisterende slægtskabskonstruktioner, kunne de blive forældre gennem "embryoadoption", og det vil Lisbeth gerne hjælpe dem til.

Da jeg udfører interviewet med Lisbeth, er det blot anden gang, jeg er blevet præsenteret for ideen om "embryoadoption”. Selvom jeg allerede havde været på klinikken en måned og vidste, at embryonerne blev destrueret, var tanken om muligheden for embryoadoption, som jeg hellere vil benævne embryondonation, ikke faldet mig ind. ${ }^{14}$ Ligesom kravet om genetisk slægtskab til mindst én af de kommende forældre, der stadig er et grundlæggende princip i den danske lovgivning, ikke havde undret mig synderligt; det skyldes ikke mindst, at biologisk slægtskab er helt centralt i alle praksisser på fertilitetsklinikken og i de mange beretninger, jeg fik under interview med kvinder og mænd, der havde gennemgået behandling.

Under mine følgende interviews med andet personale fra både den danske og den svenske fertilitetsklinik blev det tydeligt, at jeg ikke var den eneste, der ikke havde tænkt over det. Gitte, der var sygeplejerske på den danske klinik, og som ikke fandt hverken æg eller sæddonation mærkeligt, udtrykte f.eks. spontant, at det lød som "fagre nye verden".

Eksemplet illustrerer, hvordan naturlighedens paradoks etableres for noget af fertilitetspersonalet under dannelsen og håndteringen af befrugtede æg. På den ene side sættes der grænser for, hvordan æg og sæd kan mødes, og hvilke kroppe, der kan få lagt embryonerne op. Eftersom biologisk slægtskab er helt centralt for den gældende lovgivning, så er performativiteten på laboratoriet bygget op herom. I praksis er det dog også for Lisbeth og Ulla centralt, at de dagligt indgår i performativ forhandling med potentielle liv, som de er dybt engagerede i at være med til at skabe. Det bryder med de krav, der stilles til, at embryoner altid bør følge bestemte kroppe, og at de kun må opbevares i dengang to år og i dag fem år. De oplever det som modsætningsfyldt, at de skal arbejde for at skabe potentielle liv og efterfølgende destruere en stor del af dem. Det virker ikke mindst paradoksalt, fordi de samtidig har mange par, der i årevis venter på en ægdonation, og par, hvor begge parter er infertile. I den materielt-diskursive forhandling de indgår i, bliver forestillingen om, "at det mest naturlige er genetisk slægtskab", derfor udfordret, samtidig med at det er udgangspunktet for mange af de par, der er i be-

14 Embryoadoption trækker på forestillingen om, at kvinden eller parret adopterer et barn, der allerede er født. Hverken et embryon eller et barn, der skabes via dobbeltdonation, er dog allerede født, hvilket gør at jeg mener donationsbegrebet giver bedre mening at anvende. 
handling. I stedet bliver det centrale princip i deres argumentation, at ufrivilligt barnløse skal have muligheden for at få et barn - også et barn, der genetisk ikke er relateret til dem.

\section{Konklusion}

"Meeting each moment, being alive to the posibilities of becoming, is an ethical call, an invitation that is written into the very matter of all being and becoming. We need to meet the universe halfway, to take responsibility for the role that we play in the world's differential becoming." (Barad 2007, s. 396). ${ }^{15}$

I denne artikel har jeg undersøgt, hvilke implikationer naturlighedens paradokser kan få, når lys, en hund og kønsceller sætter naturen til performativ forhandling på fertilitetsklinikken. For metodisk og teoretisk at kunne konceptualisere, hvad der er i spil, har jeg trukket på agential realisme, en teori der skaber analytisk rum til at undersøge materielt-diskursive forhandlinger af det naturlige. Analyserne af de fire spørgsmål illustrerer på forskellige måder, at et materielt-diskursivt blik på naturlighedens paradoks er relevant i en kulturanalyse, fordi det har implikationer for fænomener som slægtskab, seksualitet og etik.

I det første spørgsmål om lyssætningen på laboratoriet kommer naturlighedens paradoks til udtryk i form af, at livmoderen anvendes som model for, hvordan en laboratoriepraksis kan udvikles, så der er bedst chance for at skabe befrugtede æg. Set i lyset af at det at skabe børn - også på en fertilitetsklinik - er tæt knyttet til materialitet som kroppe og celler, er det ikke så overraskende, at spørgsmålet om livmoderen spiller en central rolle for udviklingen af praksis. Det, der overraskede mig, var, at materialitetens agens spiller en konstant og overraskende rolle i de forskellige praksisser, der etableres på klinikkerne med udgangspunkt i forestillingen om livmoderen. Spørgsmålet om lys eller ej i laboratoriet er et godt eksempel på, hvordan sådan en forhandling finder sted og skabes via forskellige fænomener. I det ene indgår lys/mørke som betydningsfuldt for at efterligne naturen, i det andet er forestillingen om naturen blevet til et spørgsmål om et godt klima i inkubatoren.

I det andet spørgsmål tydeliggøres naturlighedens paradoks pga. ønsket om at bevare en hund i familien, når familieforøgelsen skal ske via sæddonation. Det

15 "At møde hvert øjeblik, at være i live med alle muligheder for tilblivelse, det er et etisk kald, en invitation, der er skrevet ind i selve materialiteten i al væren og tilblivelse. Vi har brug for at møde universet halvvejs, at tage ansvar for den rolle vi spiller i verdens forskellige tilblivelser." oversat til dansk af forfatteren. Jeg har valgt at anvende det engelske citat da begreber becoming er centralt for Barad. Desværre findes der ikke et dansk ord, der præcist rummer hvad becoming betyder. Her har jeg valgt at oversætte det med tilblivelse. 
kommende barns forældre kommer til at sætte selektionsprincipperne for donorvalg i Sverige til forhandling. I dette eksempel får familiens hund betydning, fordi ønsket om, at hunden forbliver et centralt familiemedlem, rejser spørgsmålet: Hvorfor kan man ikke få en donor uden hundeallergi? Hunden får illustreret de eksisterende diskursive modsætninger, den svenske lovgivning består af. Samtidig med at anonymitet er forbudt, og der lægges op til, at forældre fortæller barnet, at det er blevet til via donor, så er selektionsprincippet for valg af donor baseret på, at donor skal ligne den sociale far, for at det skal se ud som om, at der er genetisk slægtskab. Men med en hund, der allerede er velintegreret i familien, bliver det for de kommende forældre oplagt at argumentere for et donorvalg, der selekterer donorer med dyreallergi fra. De modsatrettede diskurser i fænomenet virker ligesom Butlers beskrivelse af, hvordan gentagende citeringer skaber parodier, der åbner op for forandring (Butler 1990). I Sverige var og er det ikke muligt at forhandle selektionskriterierne i praksis, og lovgivningen på feltet er ikke blevet udfordret, men i dag kan man i Danmark uden problemer vælge en donor, der ikke har hundeallergi, og herved forhandle hvad grundlaget skal være for en slægtskabsrelation.

Det tredje spørgsmål illustrerer, hvordan naturlighedens paradoks får betydning, når den heteroseksuelle romance mellem et æg og en sædcelle får ekskluderende effekt. Selvom denne narrativ virker genkendelig, sød, sjov og harmløs, så har den heteronormative historie ført til, at enlige og lesbiske i bl.a. Danmark og Sverige blev ekskluderet fra behandling. Det skyldes, at historien og herved sammenhængen mellem seksuel reproduktion og familieskabelse implicit er blevet anvendt som etisk-juridisk grænsedrager for adgang til fertilitetsbehandling. I Danmark blev den diskriminerende lovgivning udfordret gennem etableringen af inseminationsklinikker, der ikke faldt ind under lovgivningen. Siden er denne forestilling blevet forhandlet i en grad, så det nu i Danmark er legalt for enlige og lesbiske kvinder at blive behandlet, og kvinder fra resten af Europa kommer rejsende for at få børn via sæddonation eller køber sæd fra Danmark til hjemmeinsemination.

Det sidste spørgsmål om, hvorfor æg eller sæd skal komme fra mindst én af de kommende forældre, illustrerer, hvordan naturlighedens paradoks kan få implikationer for både forældre og personale, når slægtskabsforståelser medfører destruktion af embryoner og gør det ulovligt at anvende sæddonation og ægdonation samtidig. Ligesom ved spørgsmålet om hunden indgår der i fænomenet om at skabe befrugtede æg og graviditeter modsatrettede diskurser. På den ene side er fertilitetspersonalet dybt involveret i at skabe børn, samtidig med at de skal håndtere regler for opbevaring af kønsceller, der fører til destruktion af mange embryoner. Da der er mangel på donoræg, ville embryodonation skabe mulighed for, at ufrivilligt barnløse fik et barn. For den engagerede læge og bioanalytiker, der dagligt oplever at indgå i materielt-diskursiv intra-aktion med celler, kroppe, 
teknologi og barnløse, virker det derudover absurd at skulle destruere mulige liv. I spørgsmålet om embryodonation har de performative forhandlinger, som lægen og bioanalytikeren indgår i, så stor betydning, at naturlighedsargumentet (betydningen af genetisk slægtskab) mister sin legitimitet. For lægen og bioanalytikeren bliver princippet i dette tilfælde erstattet af, at det vigtigste er, at ufrivilligt barnløse får mulighed for at få et barn.

De fire eksempler på, hvordan naturlighedens paradoks kommer til udtryk, illustrerer på hver deres måde, hvordan praksisser performativt forhandles mellem forskellige aktører og løbende rekonstituerer eksisterende normer, men også skaber mulighed for forandringer. Det bliver muligt at se, fordi den materieltdiskursive analyse udfordrer den legitimitet, forestillinger om det naturlige har til at sætte etiske grænser. Min analyse peger derfor på behovet for at gentænke de måder, etik og ansvar gøres på i dag, når assisteret befrugtning anvendes. Samtidig med at eksemplet med lyset illustrerer, at forestillingen om det naturlige kan være en brugbar model til udvikling af visse praksisser, så illustrerer de sidste tre eksempler, at forestillingen om det naturlige kan have svære implikationer for brugerne af assisteret befrugtning, der tilmed kan føre til stigmatisering og diskrimination. Min analyse ligger således i tråd med Lykke og Brylds argumentation for, at vi har brug for at få en post-naturlig etik på dagsordenen (Lykke og Bryld 2006). Det betyder ikke en bevægelse væk fra etik, men derimod en ansvarliggørelse for, hvad der finder sted i det materielt-diskursive møde med teknologier som assisteret befrugtning. En post-naturlig etik kunne med andre ord inkludere et ansvar for, hvordan vi indgår i den verden, vi konstant er med til at skabe sammen. I dette tilfælde kunne det at tage ansvar udkrystallisere sig ved en kritisk refleksion ift., om naturen som model for praksis er relevant eller ej i en given situation. I stedet for naturen som model kunne reguleringen af og praksisser ift. anvendelsen af assisteret befrugtning basere sig på, hvilke magtrelationer, mulige stigmatiseringer og materielle konsekvenser anvendelsen af teknologien kan få. Inspireret af Susan Leigh Stars artikel: Power, technology and the phenomenology of being allergic to onions (Star 1991) kunne vi stille spørgsmålet: Cui bono? Ift. anvendelsen af assisteret befrugtning kunne dette spørgsmål blive omformuleret til spørgsmål som: Hvilke implikationer har de gældende reguleringer og praksisser af assisteret befrugtning? Hvilke implikationer har brugen af assisteret befrugtning for de implicerede aktører? Og hvad gør de kulturelle beretninger, som fletter sig ind i de måder, vi anvender assisteret befrugtning på i dag?

\section{Litteraturliste}

Adrian, Stine 2006: Nye skabelsesberetninger om æg, sæd og embryoner: Et etnografisk studie af skabelser på sædbanker og fertilitetsklinikker. LiU Press. 
Adrian, Stine Willum 2010: "Sperm stories: Policies and practices of sperm banking in Denmark and Sweden”. European Journal of Women's Studies 2010: 17, s. 393-411.

Barad, Karen 2003: "Posthumanist performativity: Toward an understanding of how matter comes to matter", Signs: Journal of Women in Culture and Society 2003: 28 s.801-831.

Barad, Karen 2007: Meeting the universe halfway: Quantum physics and the entanglement of matter and meaning. Duke University Press.

Bryld, Mette 2001: "The infertility clinic and the birth of the lesbian: The political debate on assisted reproduction in Denmark". The European Journal of Women's Studies 2001: 8 s.299-312.

Burfoot, Anette 1990: "The normalisation of a new reproductive technology". Maureen McNeil, Ian Varcoe og Steven Yealey (red.): The new reproductive technologies. Macmillan Press.

Butler, Judith 1990: Gender trouble: Feminism and the subversion of identity. Routledge

Cussins, Charis 1998: "Producing reproduction: Techniques of normalization and naturalization in infertility clinics”. Sarah Franklin og Helena Ragoné (red.): Reproducing reproduction: Kinship, power and technological innovation. University of Pennsylvania Press, s. 66-101.

Franklin, Sarah 1997: Embodied progress: A cultural account of assisted conception. Routledge.

Franklin, Sarah og Ragoné, Helena 1998: ’Introduction”. Sarah Franklin og Helena Ragoné (red.): Reproducing reproduction: Kinship, power and technological innovation. University of Pennsylvania Press, s. 1-11.

Gotllieb, Claes, Lalos, Othon og Lindblad, Frank 2000: ”Disclosure of donorinsemination to the child: The impact of Swedish legislation on couple's attitudes”. Human Reproduction 2000:15, s. 2052-2056.

Haraway, Donna 1991: Simians, Cyborgs, and Women: The Reinvention of Nature, Routledge.

Haraway, Donna 2003: The companion species manifesto, dogs, people, and significant otherness. Prickly Paradim Press.

Lag (1984:1140) Lag om insemination, ändring införd: t.o.m. SFS 2005:443.

Lag (1991:115) Lag om atgärder i forskning- eller behandlingssyfte med ägg från människa, ändring införd: t.o.m. SFS 2005:39

Liljestrand, Petra 1995: "Legitimate state and illegitimate parents: Donorinsemination politics in Sweden”. Social Politics: International Studies in Gender, State, and Society 1995:3, s. 270-304.

Lov nr. 460 af 10. Juni 1997, Lov om kunstig befrugtning i forbindelse med lægelig behandling 
Lov nr. 535 af 8. Juni 2006, Lov om ændring af lov om kunstig befrugtning i forbindelse med lægelig behandling, diagnostik og forskning m.v.

Lykke, Nina, Markussen, Randi og Olesen, Finn 2000: “There are Always More Things Going On Than You Thought!”: Methodologies as Thinking Technologies, Interview with Donna Haraway, Part Two, Kvinder, Køn og Forskning, Nr. 4, s.52-61

Lykke, Nina og Bryld, Mette 2006: ”Nye forplantningsteknologier og post-naturlig etik”. Gert Balling og Kasper Lippert-Rasmussen (red.) Det menneskelige eksperiment om menneskesyn og moderne bioteknologi. Museum Tusculanums Forlag, S. 23-50.

Marcus, George 1998: Ethnography through Thick \&Thin. Princeton University Press.

Martin, Emily 1991: "The Egg and the Sperm: How science has constructed a romance based on stereotypical male-female roles”. SIGNS: Journal of Women in Culture and Society 1991:16/3, s. 485-501

Star, Susan Leigh 1991: "Power, technology and the phenomenology of conventions: on being allergic to onions”. John Law (red.) Sociology of Monsters: Essays on Power, Technology and Domination. Routledge, s. 26-55.

Strathern, Marilyn1992: Reproducing the future: Anthropology, kinship and the new reproductive technologies. Manchester University Press,.

Thompson, Charis 2005: Making parents: The ontological choreography of reproductive technologies. The MIT Press.

Tjørnhøj-Thomsen, Tine 1999: Tilblivelseshistorier: Barnløshed, slægtskab og forplantningsteknologi i Danmark, ph.d.-række nr.12, Institut for Antropologi

\section{English Summary}

Why is the work done in darkness in one fertility lab, while it is done with the light on in another? Why is one not permitted to choose a sperm donor without a dog allergy? Why is the encounter of one ovum with one sperm cell visualized everywhere in fertility clinics, when a fertilization requires many thousand sperm cells? And why is it not possible to donate embryos when one can donate ova and sperm?

These are just some of the questions that were raised during ethnographic fieldwork at Danish and Swedish fertility clinics. Common to the four questions is the fact that they arise because nature is imitated when practices are developed and/or ethical boundaries are set. This leads to the creation of discrepancies or paradoxes that open up paths for changes. In other words the article takes its point of departure in the four questions because they are good examples of how 
conceptions of nature are negotiated in meetings between discourses and materiality.

The analysis is based on Karen Barad's theory of agential realism. This is a post-humanist theory that brings an analytical gaze to bear on the investigation of materializations and processes of change.

Although the empirical examples illustrate that change cannot be predicted, it is argued that as co-creators we have a responsibility for the world we help to create. Since the analysis illustrates that the conception of nature leads to problems for users of assisted fertilization, it is urged that a post-natural ethics should be developed by asking the question cui bono? 